ANIMAL PRODUCTION 


\section{ANIMAL \\ PRODUCTION \\ JOURNAL OF \\ THE BRITISH SOCIETY OF ANIMAL PRODUCTION}

Edited by

GERALD WIENER

J. F. D. GREENHALGH

VOLUME 5

1963

OLIVER \& BOYD LTD.

EDINBURGH AND LONDON 
PRINTED IN GREAT BRITAIN BY OLIVER AND BOYD LTD., EDINBURGH 


\title{
CONTENTS OF VOLUME 5
}

\author{
(LISTED ALPHABETICALLY BY AUTHOR)
}

AdAm, J. L., see SMIth, W. C.

Aitken, J. N., Preston, T. R., Whitelaw, F. G., Macdearmid, A., and Charleson, Euphemia B. Intensive beef production. 2. The effect of three, twelve or sixteen week weaning on the performance of AberdeenAngus crossbred cattle . . . . . . . . . .

Attken, J. N., see also Preston, T. R.

Barber, R. S., Braude, R., and Mrtchell, K. G. Further studies on the water requirements of the growing pig . . . . . .

Blaxter, K. L., and WiLson, R. S. The assessment of a crop husbandry technique in terms of animal production. . . . . . .

BraUde, R., see BARBER, R. S.

Bywater, T. L., see Dalton, D. C.

Charleson, Euphemia B., see Aitken, J. N.

Charleson, Euphemia B., see Preston, T. R.

Corbetr, J. L., Langlands, J. P., and Reid, G. W. Effects of season of growth and of digestibility of herbage on intake by grazing dairy cows

Corbett, J. L., see also LANGlands, J. P.

Dalton, D. C., and Bywater, T. L. The effect of selection for litter size and litter weight at weaning in mice maintained on two diets

DAviEs, G. E., see Hunter, R. F.

Donald, H. P. Perinatal deaths among calves in a crossbred dairy herd .

Donald, H. P., Read, J. L., and Russell, W. S. Heterosis in crossbred hill sheep

Elliotr, R. C., and Topps, J. H. Voluntary intake of low protein diets by sheep

Gibson, D., and Watson, J. H. A comparison of growth rate in twin cattle of eight breeds and crosses . . . . . . . . .

GunN, R. G., and Robinson, J. F. Lamb mortality in Scottish hill flocks .

HANCOCK, J. L. Survival in vitro of sheep eggs . . . . . . .

Harrington, G., and KING, J. W. B. A note on the prediction of muscular tissue weight in sides of beef . . . . . . . . . .

Hodges, J., see O'ConNor, L. K.

Holme, D. W., and Robinson, K. L. Some effects of dietary penicillin and zinc bacitracin on the performance of bacon pigs

Holmes, J. C., and LANG, R. W. Effects of fertiliser nitrogen and herbage dry-matter content on herbage intake and digestibility in bullocks 
Holmes, W., see White, N.

Hunter, R. F., and Davies, G. E. The effect of method of rearing on social behaviour of Scottish Blackface hoggets

KING, J. W. B. A genotype-environment interaction experiment with bacon pigs

KING, J. W. B., see also HARRINGTON, G.

LAIRD, R., Jr., and Robertson, J. B. A comparison of cubes and meal for growing and fattening pigs

LANG, R. W., see Holmes, J. C.

Langlands, J. P., Corbett, J. L., McDonald, I., and Pullar, J. D. Estimates of the energy required for maintenance by adult sheep. 1. Housed sheep

Langlands, J. P., Corbett, J. L., McDonald, I., and Reid, G. W. Estimates of the energy required for maintenance by adult sheep. 2 . Grazing sheep

LANGlands, J. P., see also CoRbett, J. L.

Lodge, G. A., and MAcPherson, R. M. The influence of plane of feeding in early life on the fertility of gilts

Macdearmid, A., see AitKen, J. N.

Macdearmid, A., see Preston, T. R.

McDonald, I., see Langlands, J. P.

Macleod, N. A., see Preston, T. R.

MacLeod, N. A., see Whitelaw, F. G.

MacPherson, R. M., see Lodge, G. A.

Mason, I. L. Symptoms of muscular hypertrophy in heterozygous steers .

Mitchell, K. G., see BARber, R. S.

O'CONNOR, L. K., and Hodges, J. Wastage and culling in dairy herds

Philip, Euphemia B., see Preston, T. R.

Preston, T. R., Aitken, J. N., Whitelaw, F. G., Macdearmid, A., Philip, Euphemia B., and MAcLeod, N. A. Intensive beef production. 3. Performance of Friesian steers given low-fibre diets

Preston, T. R., Whitelaw, F. G., Aitken, J. N., Macdearmid, A., and Charleson, Euphemia B. Intensive beef production. 1. Performance of cattle given complete ground diets

Preston, T. R., Whitelaw, F. G., and MacLeod, N. A. The nutrition of the early-weaned calf. IV. Ruminal ammonia formation from soluble and insoluble protein sources

Preston, T. R., see also Aitken, J. N.

Preston, T. R., see also WhItelaW, F. G.

Pullar, J. D., see Langlands, J. P.

ReAD, J. L., see Donald, H. P. 
REID, G. W., see CORBETT, J. L.

Reid, G. W., see Langlands, J. P.

ROBERTSON, J. B., see LAIRD, R., Jr.

Robinson, J. F., see GunN, R. G.

Robinson, K. L., see Holme, D. W.

Rollins, W. C., see TAYlor, ST. C. S.

Russell, W. S., see Donald, H. P.

Searle, S. R. Herd-by-cow interaction effects in dairy production records

SLEE, J. Birthcoat shedding in Wiltshire Horn lambs

SMrTH, C. Genetic change of backfat thickness in the Danish Landrace breed of pigs from 1952 to 1960

Smith, W. C., Adam, J. L., and Tonks, H. M. The supplementation of pig diets with oleandomycin

TAYLOR, St. C. S. Accuracy in measuring cattle with special reference to

TAylor, St. C. S., and Rollins, W. C. Body size and conformation in identical twin cattle

Tonks, H. M., see Smith, W. C.

Topps, J. H., see Elliotr, R. C.

WATSON, J. H. Inbreeding arising through artificial insemination and

Watson, J. H., see also GiBson, D.

White, N., and Holmes, W. A comparison of two methods of beef production with Sussex-Ayrshire crosses

Whitelaw, F. G., and Preston, T. R. The nutrition of the early-weaned calf. III. Protein solubility and amino acid composition as factors affecting protein utilisation

Whitelaw, F. G., Preston, T. R., and Macleod, N. A. The nutrition of the early-weaned calf. V. The effect of protein quality, antibiotics and level of feeding on growth and feed conversion

Whitelaw, F. G., see also Aitken, J. N.

Whitelaw, F. G., see also Preston, T. R.

Wilson, R. S., see Blaxter, K. L.

Proceedings of the 37th Meeting of the British Society of Animal Production, Dublin, 10-14 September 1962

Proceedings of the 38th Meeting of the British Society of Animal Production, London, 27-28 March 1963. 
Summary: Every article should have a short summary complete in itself and understandable without reference to the paper.

References: Only papers closely related to the author's work should be referred to; exhaustive lists should be avoided. Bibliographical details should be in the following order: author's name, initials, year, title of paper, title of journal (abbreviated according to the World List of Scientific Periodicals), volume of journal, first page of paper. References should be listed in alphabetical order.

Examples:

Donald, H. P., \& Purser, A. F., 1956. Competition in utero between twin lambs. J. agric. Sci., 48: 245.

Hammond, J., 1932. Growth and the Development of Mutton Qualities in the Sheep. Oliver \& Boyd, Edinburgh.

In the text, references should be made by giving author and year; papers with more than three authors should be referred to. as, for example, Hammond et al.; three or fewer authors should be written in full.

Proofs are supplied once in galley form and must be returned corrected to the Editors within seven days. Only minor corrections will be accepted; other alterations (apart from those due to printer's errors) will be charged to authors.

Reprints: Twenty-five reprints of each paper will be supplied free to authors on request. Further copies may be purchased if the order is sent at the galley proof stage.

Animal Production is published three times a year, each number consisting of about 96 pages. Annual subscription for every 3 numbers is $45 \mathrm{~s}$. (or $\$ 7.50$ in the U.S.A. and Canada) and the price for a single number is $17 \mathrm{~s} .6 \mathrm{~d}$. (or \$2.75).

Business matters, including regular subscriptions and sales (the current Journal, back numbers, the Proceedings of the British Society of Animal Production (predecessor to Animal Production), and reprints), should be addressed to Messrs. Oliver \& Boyd Ltd., Tweeddale Court, 14 High Street, Edinburgh, 1.

Editors: GERALD WIENER, A.R.C. Animal Breeding Research Organisation. J. F. D. GreENHALGH, Rowett Research Institute.

Front cover centrepiece: From rock painting (about 4000 B.C.) at Tassili (Sahara desert) 


\section{CONTENTS}

Whitelaw, F. G., Preston, T. R., and Macleod, N. A. The nutrition of the early-weaned calf. $V$. The effect of protein quality, antibiotics and level of feeding on growth and feed conversion . . . . . . . . . . 227

HANCOCK, J. L. Survival in vitro of sheep eggs _ . . . 237

Preston, T. R., Aitken, J. N., Whitelaw, F. G., McDearmid, A., Philip, Euphemia B., and MacLeod, N. A. Intensive beef production. 3. Performance of Friesian steers given low-fibre diets.

Holme, D. W., and Robinson, K. L. Some effects of dietary penicillin and zinc bacitracin on the performance of bacon pigs

SMITH, C. Genetic change of backfat thickness in the Danish Landrace breed of pigs from 1952 to 1960

ElliotT, R. C., and ToPPS, J. H. Voluntary intake of low protein diets by sheep

BARBer, R. S., Braude, R., and Mitchell, K. G. Further studies on the water requirements of the growing pig. . . .

KING, J. W. B. A genotype-environment interaction experiment with bacon pigs

Donald, H. P., Read, J. L., and Russell, W. S. Heterosis in crossbred hill sheep

SLEE, J. Birthcoat shedding in Wiltshire horn lambs . . 301

Dalton, D. C., and Bywater, T. L. The effect of selection for litter size and litter weight at weaning in mice maintained on two diets

Harrington, G., and KING, J. W. B. A note on the prediction of muscular tissue weight in sides of beef 